\title{
REFLECTION OF ETHNIC VOICE IN THE FICTIONAL WORLD OF YESHE DORJEE THONGCHI: A CRITICAL STUDY OF THONGCHI'S SELECTIVE NOVELS
}

\section{RIMA RANI NATH}

Assistant Professor (Contractual), Department of English, Furkating College, Golaghat, Assam, India

\begin{abstract}
North-Eastern region of India is the abode of a large number of ethnic groups who have varied socio-cultural traditions. This cultural diversity and colourful traditions of different tribes find expression in the writings of some literary figures that belong to the tribal communities of this region. Yeshe Dorjee Thongchi is the most distinguished novelist of Arunachal Pradesh who very beautifully and realistically mirrors the ethnic voices in his novels. Thongchi's fictional world basically revolves around the life and society of the innocent tribal people living in the darkest and remotest area of Arunachal Pradesh. All of Thongchi's novels reflect the social diversity and rich cultural heritage of Arunachal Pradesh and his two famous novels 'Sonam' (1982) and 'Mouna Ounth Mukhar Hriday' (2005) are no exception of this. 'Sonam' was Thongchi's first novel which is based on the custom of polygamy and polyandry that prevalent among the Monpa tribe and according to which two or more men can share a common wife. The second novel, 'Mouna Ounth Mukhar Hriday' (Silent Lips and Murmuring Hearts), was Thongchi's masterpiece, which portrays the life and rituals of two different tribes- Wangi (Nyishi), on the one hand and Serdukpen on the other. This novel centered on a very tragic and heart-touching love story set against the backdrop of Arunachal Pradesh going through a process of transition.

The objective of the study is to provide a comprehensive understanding of the tradition, custom, rites and rituals of different Arunachalee tribes that have been reflected in Thongchi's two famous novels- 'Mouna Ounth Mukhar Hriday' and 'Sonam'. The study also attempts to explore how the strict observance of such customs and rituals give birth to some problems and issues like identity crisis and marital conflict among these tribes.

KEYWORDS: Ethnic Voices, Polyandry, Monpa, Nyishi, Serdukpen, Arunachal Pradesh, Customs, Marital Conflict, Identity Crisis
\end{abstract}

Received: Jun 09, 2020; Accepted: Jun 29, 2020; Published: Jun 30, 2020; Paper Id.: IJMPERDJUN2020308

\section{INTRODUCTION}

The genre of novel has always been considered as a realistic account of society that mirrors the human life either in whole or in fragmentation. In North - East India, a large number of tribal literature have been produced which very vividly describe the colourful traditions, rites and rituals of the tribal communities. Yeshe Dorjee Thongchi is the most eminent writer of Arunachal Pradesh who very enthusiastically narrates the life and society of Arunachalee tribes in his fiction. Yeshe Dorjee Thongchi, whose theme is mostly about the little known communities of Arunachal Pradesh, is said to be the first author who has actually taken their inside stories to the outside world. ${ }^{1}$ Thongchi entered into the field of Assamese fiction with his first novel Sonam (1981). But it was his magnum opus Mouna Ounth Mukhar Hriday (Silent Lips and Murmuring Hearts) which established him as the most leading

\footnotetext{
${ }^{1}$ https://arunachal24.in. Title: Yeshe Dorjee Thongchi. Time: 4:30pm.
} 
and prominent Assamese fiction writer. Both these novels have been translated into English which in turn bring worldwide fame for him.

In the novel Mouna Ounth Mukhar Hriday, Thongchi beautifully reflects two ethnic voices- the Nyshi on the one hand and the Serdukpen on the other. The novel very brilliantly describes how these two tribes discovered the outside world after having engaged in construction of a road into the mountains especially from Bomdila to Dirang. The novel mainly centers on the saga of undying love between Rinsin (the protagonist) and Yama (the heroine) who belong to two different tribal communities and who happened to meet during the construction of the road. Their eternal love transcends all the hindrances that had been forged by their tribal society. The strict social norms of their tribal society had never allowed them to unite and the novel vividly describes how the lovers were ruthlessly separated by their conservative society.

In the novel 'Sonam', Thongchi portrays, in an excellent manner, the custom of polyandry system that has been practiced within the Monpa tribe of Arunachal Pradesh. At the same time, Thongchi also throws light on the physical, mental and emotional hardships faced by the male shepherd protagonist, Lobjang, residing in the high mountainous regions of the Himalayas in Arunachal Pradesh who has to share his beautiful wife, Sonam, with an another person. From the beginning till the end, the novel shows how the adoption of polyandry system leads to the utmost marital conflict in human life.

\section{REFLECTION OF ETHNIC VOICE IN “MOUNA OUNTH MUKHAR HRIDAY”(SILENT LIPS AND MURMURING HEARTS)}

Yeshe Dorjee Thongchi, in his novel 'Mouna Ounth Mukhar Hriday', wholeheartedly makes an effort to highlight the colourful and diverse traditions, customs rites and rituals of two tribal communities- the Nyishi and the Serdukpen. Thongchi, while discussing the different traditions and rituals of these two tribes, depicts a series of sharp contrast between them and this very contrast echoes the problem of identity faced by the members of both the tribes. Hence, this novel can also be viewed from the perspective of identity crisis. It shows how both these tribes tried to protect and maintain their own identity throughout the novel.

From the very beginning, both the Serdukpen and the Nyishi tribe consider themselves to be the superior to one another. Especially the Nyishi people think that they are the superior of all. Tadak, a Nyshi boy, very boastfully expresses their superiority in the following lines:

"Ngishak (Serdukpen) tribe is too inferior to us. Our Nyishi tribe is the

superior among all other tribes in this world. We collect tax from the Bangru

tribe and this Bangru tribe again collects the same from the Ngishaks.

The Bangroes, who always shiver in fear of the Nyishi, likewise in front of those

Bangroes , again the Ngishak react like a mouse in innate fear of cat."

(Thongchi, p.23)

Thus, it is clear that Tadak, not only proves their superiority over all other tribes in the world but at the same time he also tried to humiliate the Sherdukpen tribe by keeping them at the margin among the tribal communities in the world. 
Every time it was Tadak who undermines the greatness of the Serdukpen tribe by making comparison between them. Tadak, very poignantly criticizes the rituals performed by the Serdukpen people. According to him, the way they (Serdukpen tribe) perform religious activities is very ridiculous. Unlike the Nyshi people, who worship God by offering blood of the animals like pig, cook and mithuns, the Serdukpen tribe worship God only by chanting mantras. Tadak very sarcastically remarks that the Serdukpen priests are not holy persons because they cannot chant the mantras without following the book. Whereas the Nyshi priests possess some divine power which make them holy persons and unlike the Serdukpen priest, they can easily recite the mantras. Hence, Tadak again proves their superiority over the Serdukpen people.

For the Nyishi people, the Serdukpen tribe is inferior to them regarding their food habits. Because the Serdukpen people do not know the process of paddy cultivation due to which they have to live on corn. But the Nyishi people know how to cultivate paddy and this very act again established them as the superior tribe across the world.

Besides, the marriage rituals of both the tribes are different from each other. Among the Nyishi people there is a ritual of paying the bride price in exchange of mithuns. But the Sherdukpen tribe performs the ritual of offering the "eri silk sadar" to the bride instead of 'mithuns'. The Nyishi tribe takes pride in offering mithuns and for them this ritual undoubtedly established them as a superior tribe.

Both the tribes consider each other as their enemies and they see one another in a suspicious way. They did not want to work together and it is evident when they repeatedly request Dilip Saikia, the field assistant, not to mingle them. The Sherdukpen people even did not want to build their camp next to the Nyishi people's camp because they were very much afraid by the thought of being attacked by the Nyishi people. Hence both of them did not want to make friendship with each other.

As the novel progresses, it seems that both the tribes become friends. But they did not want to go beyond friendship because they wanted to protect their identity by not breaking their tradition in any condition. But the strict social norms of orthodox tribal society cannot prevent lovers to become closer and hence the hero, Rinsin Norbu, who belongs to the Sherdukpen tribe and Yama, a girl from the Nyishi tribe, fall in love with each other during the construction of the road. Their love transcends all the customs and rituals of their community. They can never express their love due to the language barrier between them but they can better understand their feeling for each other. Both of them knew that their love can never be fulfilled; their society will never allow them to unite. So Yama planned to elope with Rinsin but she was kidnapped by her in-laws, who gave mithuns for her. It was Yama's brother Tadak, who informs her in-laws about her elopement and suggested them to take her away because he did not want Yama to marry a person from the Serdukpen tribe which is inferior to them. Thus, just to maintain and protect their Nyishi identity, Tadak throws his dear sister into the ocean of tears and suffering and never thinks about her happiness though he was well aware that Yama's happiness is only with Rinsin. Even Rinsin thought that if he marries Yama, it would be a great dishonor to their Serdukpen community; it may threaten their identity. Thus the novel ends in a very tragic note as the lovers are savagely separated due to their so called strict social norms.

Another important aspect that is apparently visible in the novel is the status of women in the tribal community. Since time immemorial, every society considered women as a mere puppet in the hands of man. In a patriarchal society, women are incessantly exploited, humiliated, oppressed and subjugated. Through Yama's character, Thongchi reflects the 
miserable condition of a woman in a male-dominated society who does not even have the right to choose her life-partner. Being a woman, she is treated as the subordinate; as the 'Other'. Hence, Yama is brutally separated from Rinsin by her own brother.

Apart from this tragic love story, Thongchi also portrays the superstitious nature of the innocent tribal people who believe in the existence of supernatural powers and fear to go to the forest after the evening falls. This superstitious nature of the tribal people is very amusingly described in many chapters of the novel especially in the chapter 1 when Rinsin and the other girls namely Tsereng Jangmu, Chauki Wangmu and Doima encountered Yama in the forest and the girls thought her to be a night hag ('Banmanuh') who disguised as a beautiful lady only to entrap Rinsin.

Besides, the chapter 7 of the novel again reflects the same thing when Rinsin, during the construction of the road, went to get the 'lesang-mintu flower' for Yama and fell into danger. Both the tribe thought that Rinsin became under the spell of an evil spirit who pushed him into danger. So both the tribe performed some ritual in order to get rid of that ghost. They are so innocent that they never came out of the dark ages and were not even familiar with money and shop until Dilip Saikia, whom they called 'Mohori Babu', gave them wages for their work and informed them about shop. These tribal people are so meek and mild that they do not know anything about hypocrisy and artificiality. Their hearts filled with pristine purity and primeval innocence. They are devoid of the rays of knowledge and hence supposed the vehicles to be a beast that may harm them.

These tribal people live in the remotest area of Arunachal Pradesh and they never get the light of education and the knowledge of modern technology. Before came out of their village and engaged in the construction of the road, they had never imagined such varieties of people residing in this world of 'Donipol' (Donipol is the name of the God worshipped by the Nyishi people). They thought that they were the only people in the world. As Yadu, the sister of Yama and Tadak, says:

"Today again came a new group of people from somewhere. Completely strange

in apparel, strange in conversation. Before coming here, I had never imagined of such

varieties of people except Nyishi in this world of Donipol. I thought that we Nyishi and

Shulung are the only people in this world."

(Thongchi, p-2)

Thus, in the novel "Mouna Ounth Mukhar Hriday", Thongchi, not only depicts the colourful and diverse traditions of two different tribes but at the same time, presents them as ignorant, fearful, superstitious, unsophisticated and devoid of malice. They are very much aware of their tribal identity and never want to compromise with it. Although both the tribes became friends, they did not let Rinsin and Yama to get married. They never hated each other but they just did not want to violate the social norms and tradition of their community. Their only fear was that if this marriage took place then it would not only be a great dishonor to their community but it may also threaten their identity. Questions will be raised on their superiority. Hence they always preferred to remain within the four walls of their community.

Towards the end of the novel, Yama realized that a road can be constructed by cutting the mountains that connects the inhabitants of plains to the hills but these two tribes will never break the invisible mountain between them. When Yama came to know about her pregnancy, she decided to give birth to Rinsin's child because it was the only sign of their eternal 
love that transcends all the barriers of this physical world. Secondly, for Yama the child that is growing in her womb will always remain as a symbol of protest for this ever going identity conflict between the two tribes.

\section{REPRESENTATION OF ETHNICITY IN THONGCHI'S "SONAM"}

Unlike "Mouna Ounth Mukhar Hriday", the novel "Sonam" very realistically and vividly describes the marital conflict caused by the practice of polyandry system among the Monpa tribe. The novel presents before us, the mental and emotional conflict of a young Brokpa shepherd man, Lobjang, due to his wife, Sonam, who is being shared by an another man. Lobjang lives in the Sakteng village but he has to spend the greater part of his life in the Broke, the animal farm that is situated at the top of Choksum hills. Whenever Lobjang comes down to his village, he brings with himself Mar (milk fat), churpi, a type of cheese made from milk, and sheep wool. He carries these items to far off places like Tawang, Kalaktang, Rupa and Dirang and in the neighbouring country Bhutan where he makes use of the barter system to exchange the items with plenty of rice brought from Assam. ${ }^{2}$

Lobjang got married to a very beautiful girl, Sonam but his conjugal life was never running smoothly because of their separation caused by his working condition. His young and newly wedded wife Sonam lives in his native village, Sakteng, whereas he has to remain at his farm which is very far from his village. Sometimes, Lobjang has to stay at his farm for more than twenty days. So he is very sad with his condition. His mind is always preoccupied with the thought of his wife. His heart and mind long for his beautiful wife and this is evident when Tikoro, his friend, remarks:

"I am sure your mind has already flown to her, and here we have a lifeless body."

(Thongchi, 15)

Lobjang wanted to take Sonam with him to his farm but he could not do so because of some customs that were prevalent in his community. There is a belief among the Brokpa tribe, according to which if Lobjang takes his wife, Sonam, to the farm and lives with her; it would diminish the purity of the place. In other words, their attempt to make sexual relationship at the farm will evoke the wrath of the 'Sungmu', the god of wealth which resulted in the invitation of misfortune and the outbreak of epidemics leading to the death of animals living in that farm. This very belief of the Monpa tribe again reflects the superstitious nature of the tribal people as it was reflected in the former novel.

One day Lobjang went home some twenty days later. He was desperate to meet his wife as soon as possible. He reached his village after the evening falls. When he approached his house, he heard the sound of two people talking inside the house. Suddenly he saw that a young man named Pema Wanchu came out of the house and left without saying anything to him. Lobjang became very angry and frustrated because he never expected his wife to become intimate with another man. As he entered into the bedroom, he discovered the impression of two bodies on the pillows and the bed which ascertain his doubt that his wife, Sonam, had committed adultery and used to sleep with another man. He wanted to kill his wife due to such act of betrayal and disloyalty but he could not do so as he loves his wife more than anything. Sonam, instead of feeling remorse and penance, very assertively speaks the following lines in her defense:

\footnotetext{
${ }^{2}$ Kumar,Dr. Kailash. “TribalL MaritalL Relationship: A Reading of Yeshi Dorjee Thongchi's Sonam”pg. 318.
} 
"What wrong have I done? It's me who sleeps alone everyday, and finding me staying all alone in the house the boys of the village come and trouble me all the time. Being a helpless woman what am I to do, how can I keep them away? And that Pema Wangchu? He paid no heed to my repeated warnings. How I pleaded with him not to come near me. Now what should I do? You tell me! Either you take me to the Broke to stay with you or otherwise you might as well kill me ..... ?" Sonam started to sob".

(Thongchi, 20)

The above mentioned statement highlights the pathetic condition of Sonam who, despite being a married woman, had to lead a very solitary and insecure life in the absence of her husband. The village youth take the advantage of this pitiable and helpless condition of Sonam and try to build up illegitimate relationship with her. Sonam, being alone at home, is regarded by the lecherous village boys as a juicy morsel that can satisfy their male libido. Sonam represents the whole race of womankind who after getting married wishes to have a very happy conjugal life. But due to the separation from her husband, she can never fulfill her sexual urge. It is for this reason that she submitted herself to those boys who has been seeking for such golden opportunity. Hence Sonam, in the absence of her husband, suffered a lot. She had no choice except to sleep with Pema Wanchu to gratify her sexual desire.

Lobjang also knew that being a woman it is really very difficult for Sonam to stay alone at home. She is in urgent need of a male companion who can provide her security with love, care and affection. The one and only solution to this difficult situation is to adopt the polyandry system which is very favourable among the Brokpas. In Lobjang's community a woman whose husband stays away from her in a distant farm, can share a co-husband for her safety. Sonam also felt the need of a co-husband and ready to share herself between Lobjang and Pema Wangchu.

Besides the polyandry system, casteism also plays a vital role among the Brokpas and this is evident when many people from the Brokpa community refused to accept Pema Wangchu as Sonam's co-husband because the former was belong to another caste which, in the words of Brokpa people, was inferior to them. Lobjang's friend Kejang strongly opposed Pema Wangchu as Sonam's co-husband because both Lobjang and Pema Wangchu belonged to two different castes. If Sonam becomes pregnant, it would be difficult for the society to identify the real caste of that child. Even Pema Wangchu's parents were not happy with this relationship. Pema's father, Tsewang, opined that his son Pema was free to marry any of his brother's wife instead of marrying Lobjang's wife as he belonged to a different caste and for him their caste is superior to Lobjang's caste.

A very careful and close reading of the novel discloses the fact that among the Brokpa community, the village hierarchy played a vital role in determining the social norms especially the matrimonial laws. It is apparent when the village head Tsopa put forwarded some conditions in order to fulfill the proposed marriage between Pema and Sonam. Pema, before going to marry Sonam, had to follow some set rules. The first and foremost condition was that Pema would denounce his caste and accept Lobjang's title. Secondly, Pema's father, Tsewang would disown his son and Pema would lose share in his father's property. ${ }^{3}$

Another important issue regarding the marital system of Brokpa tribe is that the senior husband has to share his property with his co-husband. So Tsopa also ordered Lobjang to share everything with Pema including his responsibility. Hence after their marriage, Lobjang shared everything with his co-husband Pema. It is evident when Lobjang told Pema:

\footnotetext{
${ }^{3}$ Ibid, page- 320 .
} 
"The animals that you see, the cows and sheep, the entire lot from today are all yours. From now on I am no longer the sole owner of the property, - it belongs to us both. You have an equal share and responsibility, so look after the animals well."

(Thongchi, 36).

With the progression of the novel, it becomes clear that Pema Wanchu failed to fulfill his duty properly. According to the agreement both Lobjang and Pema had to spend equal number of days on the firm and at home. Lobjang always performed his duty properly but when it was Pema's turn to stay on the firm, he just tried to neglect his duty. When one night a snow leopard attacked the firm and killed one of the sheeps, Pema instead of protecting the sheeps, escaped from the firm and arrived at home before due time. Lobjang asked Pema to go back to the firm and to protect the animals but he was not in a mood to go back. Even Sonam tried to defend Pema by showing her unwillingness to let him go at that time of night. Lobjang, on seeing Sonam's concern for her second husband, suffered mentally and emotionally and his soul covered with despondency and dejection.

That very night all of them had to spend their night together in the same room. Even Sonam and Pema shared the same bed. Lobjang could not sleep that night as he never imagined his beloved wife to sleep with another man. That was a disgusting scene for him which he could not tolerate any more. It seems that after her second marriage, Sonam stop thinking about Lobjang. She shifts all her love and affection to Pema Wanchu as if he becomes the universe for her. That night Lobjang was lying alone in one corner of the room and his heart was lamenting and wailing for justice. But now all his tears and wailings are of no worth because he himself accepted the polyandry system and was ready to share his wife with Pema.

Throughout the novel, it seemed that Lobjang left no stone unturned to fulfill the marriage under the polyandry system but every time it was he who suffered a lot due to this system. When Sonam gave birth to a baby girl, several thoughts occupied his mind regarding the biological father of that child. He thought Pema Wangchu to be the real father of that child because Sonam spent more time with Pema. Thongchi beautifully mirrors the internal conflict of Lobjang in the following words:

"He was not sure who might be the real father of the child. Pema Wangchu or he?

Perhaps it might be Pema Wangchu's child as he is now spending more time with Sonam.

As he thought deeper, he lost his spirit and felt miserable. With great effort he suppressed

his doubts over the fatherhood of the child, as it mattered no more after he had accepted

Pema Wangchu as his co-husband. Whoever might be the real father, it was their child

equally now”.

(Thongchi, 67)

Thus it is clear that although Lobjang was uncertain about the fatherhood of that child, he was ready to accept the child as his own. But later on Sonam revealed before Lobjang that he was the real father of the child. 
After reading of the text, one can easily determine the fact that the polyandry system is not a permanent solution rather it is an irresolvable problem that completely destroys the husband-wife relationship. It is clearly visible in the novel that none of the characters seemed to be happy by entering into the polyandry system. They began to quarrel among themselves and each time Sonam tried to defend Pema and which in turn caused emotional crisis in Lobjang's mind. Pema was the first to make quarrel with Lobjang because he sold a cow to repay his debt which he had borrowed from Ngawang. When Lobjang opposed this act, Pema started leveling charges against Lobjang by saying that if Lobjang could sell cows in the name of buying foodgrains then why he could not sell a cow to repay his debt. He further said that he had that much right over the property as Lobjang had. He called Lobjang a miser and alleged that Lobjang had exploited him by keeping him hungry on the farm. This enraged Lobjang and he ordered Pema Wangchu to get out from his house. ${ }^{4}$

But Sonam vehemently accused Lobjang for treating Pema like a subordinate. She also reminded Lobjang about Pema's status in the house which is equal to him and hence he did not have any right to throw Pema away from the house. Lobjang angrily told Sonam that she was a very lustful woman who wanted to keep Pema only to satisfy her lust. On hearing this, Sonam replied:

"What do you take me for? Do you think that I am a piece of stone or a log of wood? Am I not a human being, don't I also have feelings? What about my desires? Have you ever given a thought to my suffering? You have always stayed away from me. How much strength do you think you have? What should I have done? Slept with a $\operatorname{dog} \ldots . .$. ?"

(Thongchi, 80-81).

Thus, despite being a married woman, her sexual desire had never been gratified because her husband, Lobjang, had to stay away from her due to his working condition. This very fact compelled her to sleep with another person (Pema Wangchu) and to keep him as her husband's substitute. Hence, the unfulfilled sexual desire forced her to keep two husbands at a time.

Towards the end of the novel, Sonam met her untimely death and Lobjang was left all alone with two children to take care of. After the death of Sonam, her sister Tsering Dolma took the responsibility of her sister's children. Tsering Dolma was completely different from her sister Sonam regarding her opinion on the institution of marriage. For Sonam, polyandry system was the only solution to the problem that she had undergone, whereas Tsering Dolma believed in monogamy. She felt that by sharing oneself with two men would always create problem and completely destroyed the husband-wife relationship. She wanted to build a new world which include Lobjang and Sonam's two children. But she would never allow Pema Wangchu to enter into her new world.

The novel, 'Sonam', mainly revolves around the institution of marriage and this is evident when Ngoiru, the father of Tsering Dolma, opined that Lobjang needs another Sonam and told his daughter Tsering Dolma,

"If the world is to survive, man and woman must live together, because it is they who create life. So go ahead and without fear began your new life, - keep the world alive, - nobody has the right to destroy it."

(Thongchi, 124)

\footnotetext{
${ }^{4}$ Ibid, page-321-322.
} 
Hence, after reading of the novel, one can come to the point that in "Sonam", Thongchi discloses the evils of polyandry system that has been playing a pivotal role within the Brokpa community. Through the male protagonist, Lobjang, Thongchi throws light on the hardship as well as the mental and emotional crisis of the stakeholders of polyandry system. Throughout his life, Lobjang suffered a lot. He did not want to share his wife with anybody else whom he loved the most. He could not tolerate to see his wife sleeping with another person. Many a time, his mind became rebellious but he had to endure all these because the community he lived in wholeheartedly welcomed the polyandry system and allowed Sonam to keep Pema as her second husband.

\section{CONCLUSIONS}

To conclude, it can be said that Yeshe Dorjee Thongchi, in both the novels, beautifully reflected the diverse traditions, customs, rites and rituals of different tribes of Arunachal Pradesh. But at the same time, Thongchi, by reflecting the customs and rituals of different tribes, exposes the underlying evils of these social norms. Most of the times, Thongchi's protagonists become his mouthpiece and criticize the age old and orthodox customs of these conservative tribal communities. In the novel "Mouna Ounth Mukhar Hriday", both the hero and the heroine, Rinsin and Yama respectively, silently protested against the norms of their community and wanted to withdraw this by becoming closer to each other and making love between them. In "Sonam" also, the protagonist Lobjang never seemed to be happy with the polyandry system, rather he would be happy if his community prevented his wife, Sonam, from getting second marriage. Although he suppressed his voice, his heart and soul always sought for protest and lamented for justice. Most of the time, he revealed his discontentment, grievances, anger and rebellion by scolding Sonam and Pema Wangchu as well. Hence, in many cases the people from these communities feel superiority-inferiority complex due to the strict observance of such rituals. Sometimes they feel identity crisis and at another time they suffered internal conflict leading to the utmost mental and emotional hardship.

\section{REFERENCES}

1. Thongchi, Yeshe Dorjee. “Mouna Ounth Mukhar Hriday”. Guwahati: Banalata Publishers, 2015. Reprint.

2. Thongchi, Yeshe Dorjee. “Sonam”. Delhi: Spectrum Publications, 2001. Print

\section{ONLINE ARTICLE}

3. Dutta, Dr. Juri. Representation of Ethnic Worlds in Select Fictions of India: A Comparative Study. www.tezu.ernet.in/casms/pro2.php. Time: 5:45 pm.

4. Kumar,Dr. Kailash. “Tribal Marital Relationships: A Reading of Yeshe Dorjee Thongchi's Sonam” time: 7:30 pm.

5. Nath, Rima Rani. “Theme of Identity Crisis in Yeshe Dorjee Thongch's Novel 'Mouna Ounth Mukhar Hriday' ( Silent Lips and Murmuring Hearts)". Time: 9:00 pm.

6. “Tribal Identity Crisis and Solution”. Unit-4. Egyankosh.ac.in>bitstream. Time: 10 pm.

7. "Folklore in the Novels of Yeshe Dorjee Thongchi" (Chapter-V). shodhganga.inflibnet.ac.in>jspui. Time: 3:30pm.

8. https://arunachal24.in. Title: Yeshe Dorjee Thongchi. Time: 4:30pm.

9. Aro, G C, et al. "Assessing the Contribution of the Military Regimes to Political Developments in Post Independent Nigeria, 1966-1999." International Journal of Humanities and Social Sciences (IJHSS) 4.5 (2015):35-42 
10. Azon, Senakpon A. Fortune. "Voice, Language, and Storytelling: The Craft of Narrative Experimentation in John Edgar Wideman's Fiction." International Journal of English and Literature (IJEL) 8.1 (2018):65-76

11. Saboo, J M. "Rita Dove's Satire on the Overlooked Events in the World History." International Journal of English and Literature (IJEL) 4.6 (2014):1-8

12. Remy, Kumari. "The Role of Gender and Warfare in the Fiction of Ernest Hemingway." International Journal of Linguistics and Literature (IJLL) 7.5 (2018):57-60

13. Hadidi, Yaser., and Roghiyeh. Nazerfar. "Comments on the system of lexical cohesion in a sample of English fiction"." International Journal of Linguistics and Literature (IJLL) 3.5 (2014): 41-60. 